\title{
Nightmares and bad dreams among individuals with musculoskeletal pain: a link to vitamin $\mathrm{D}$ and calcium
}

\author{
Khalid K. Abdul-Razzak, Mohammad J. Alkhatatbeh \\ Department of Clinical Pharmacy, Faculty of Pharmacy, Jordan University of Science and Technology, Irbid, Jordan
}

\begin{abstract}
Nightmares are frightening or disturbing dreams that awaken sleepers while bad dreams are disturbing dreams that do not awaken sleepers. Both types are known to be associated with psychological symptoms including anxiety and depression. Chronic pain is often comorbid with psychological symptoms and vitamin D deficiency increases risk of chronic musculoskeletal pain (MSP), which in turn is associated with increased risk of anxiety and depression. We aimed to investigate associations between types of dreams, psychological symptoms, vitamin D, and calcium intake in individuals with MSP. The study included 191 outpatients with MSP and 191 age/gender matched healthy controls. Psychological symptoms were assessed using Hospital Anxiety and Depression Scale. Serum vitamin D was measured and daily calcium intake was estimated. Participants were asked about types of their dreams (normal, bad, or nightmares) during the past month. Binary logistic regression was used to find predictors of MSP and bad dreams and nightmares. Bad dreams and nightmares, vitamin D deficiency, low calcium intake, anxiety, and depression were more prevalent in cases versus controls ( $\mathrm{Ps}<0.001)$. Chi-square analyses showed that types of dreams were associated with anxiety, depression, and $\operatorname{MSP}(\operatorname{Ps}<0.001)$. Participants with normal dreams had higher vitamin D $(\mathrm{P}<0.01)$ and calcium intake $(\mathrm{P}<0.001)$ and lower anxiety and depression scores $(\mathrm{Ps}<0.001)$ compared to participants with bad dreams and nightmares. Anxiety, depression and MSP were predictors for bad dreams and nightmares. Further studies are required to assess if vitamin D supplementation and increasing calcium intake may improve MSP, psychological symptoms and thus prevent nightmares and bad dreams.

Correspondence: Khalid K. Abdul-Razzak, Department of Clinical Pharmacy, Faculty of Pharmacy, Jordan University of Science and Technology, PO Box 3030, Irbid-22110 Jordan.

Tel.: +962.2.7201000 - Ext. 23536 - Fax: +962.2.7201075.

E-mailkkalani@just.edu.jo
\end{abstract}

Funding: the research was supported by grand from Deanship of Research, grant number 238/2020.

Contributions: KKA was responsible for study design, data collection, results interpretation and manuscript drafting. MJA was responsible for statistical analysis, results interpretation, manuscript drafting and editing.

Conflict of interests: the authors declare no potential conflict of interests.

Availability of data and material: all data are within the manuscript.

Ethical approval and consent to participate: the study procedure was ethically approved by the Institutional Review Board of Jordan University of Science and Technology. Written informed consents were obtained from all participants.

Citation: Abdul-Razzak, K.K., \& Alkhatatbeh, M.J. (2021). Nightmares and bad dreams among individuals with musculoskeletal pain: a link to vitamin D and calcium. Research in Psychotherapy: Psychopathology, Process and Outcome, 24(2), 156-164. doi: 10.4081/ripppo.2021.533

Received for publication: 9 March 2021.

Revision received: 13 July 2021.

Accepted for publication: 17 July 2021.

This work is licensed under a Creative Commons Attribution NonCommercial 4.0 License (CC BY-NC 4.0).

${ }^{\circ}$ Copyright: the Author(s), 2021

Licensee PAGEPress, Italy

Research in Psychotherapy:

Psychopathology, Process and Outcome 2021; 24:156-164

doi:10.4081/ripppo.2021.533
Key words: Nightmare; bad dream; vitamin D; calcium; anxiety; musculoskeletal pain.

\section{Introduction}

Dreams are one of the most delightful and puzzling aspects of sleep that occur every night in almost all individuals. They are the most exciting phenomenon in psychology and neuroscience (Nir \& Tononi, 2010). However, dreams can be annoying, bad unpleasant and nightmares frightening, or disturbing dreams (Robert \& Zadra, 2014; Scarpelli, Bartolacci, D'Atri, Gorgoni, \& De Gennaro, 2019). Nightmares and bad dreams are overlapping and are common forms of parasomnia. Nightmares are typically frightening or disturbing type of dreams, which imply nocturnal awakening, while bad dreams are disturbing dreams with no nocturnal awakening (Hasler \& Germain, 2009; Nadorff et al., 2014; Ross Levin \& Nielsen, 2009). Despite phenomenological similarities between nightmares and bad dreams, it remains unknown if they are separate phenomena that are varying in intensity (Hasler \& Germain, 2009; Nadorff et al., 2014; Ross Levin \& Nielsen, 2009).

In general, nightmares and bad dreams may occur in the general population including children, adolescents, young adults and elderly with a higher prevalence in females compared to males ( $\mathrm{Li}$, Zhang, Li, \& Wing, 2010; Schredl, 2014). They may occur in these populations following frightening or highly emotional distress events 
(Ohayon, Morselli, \& Guilleminault, 1997; Ross Levin \& Nielsen, 2009). In addition, nightmares have been associated with several psychiatric conditions, including anxiety and depression (Lemyre, Bastien, \& Vallières, 2019; Levin \& Fireman, 2002; Swart, van Schagen, Lancee, \& van den Bout, 2013). Thus, nightmares and bad dreams may represent as a secondary syndrome to mental disorders (Nadorff et al., 2014). However, the origin of such dreams is still unclear (Lemyre et al., 2019).

Depending on their frequency and on the psychological profile of the subject, nightmares may have a substantial negative impact on an individuals' daytime functioning, including emotional distress, cognition problems, sleepiness, and fatigue or low energy. In addition, nightmares are associated with increased suicide ideation and behaviors, and they are associated with increased risk of developing symptoms of many types of mental illnesses (Gieselmann et al., 2019; Nadorff et al., 2014; Ohayon et al., 1997). Thus, treatment of disturbing dreams is of importance, and will have substantial clinical relevance on dreamers.

Chronic pain is often comorbid with anxiety and depression across diverse populations and these three conditions have long been recognized to coexist (Abdul-Razzak, Mayyas, \& Al-Farras, 2018; Gureje et al., 2008). Our previous studies have reported that low serum vitamin $\mathrm{D}$ and low calcium intake may increase the risk of musculoskeletal pain (MSP), which in turn is associated with increased risk of anxiety and depression (Abdul-Razzak, Almanasrah, Obeidat, \& Khasawneh, 2018; Abdul-Razzak et al., 2019; Abdul-Razzak, Mayyas, et al., 2018). Therefore, decreased serum vitamin D levels and decreased calcium intake may be associated with the development of nightmares and bad dreams indirectly through their association with the psychological symptoms and MSP.

Therefore, our aim was to investigate associations between nightmares and bad dreams, anxiety and depression symptoms, serum vitamin D levels, and daily calcium intake in individuals with MSP compared to healthy controls with no MSP. We hypothesized that participants with MSP have significantly more bad dreams and nightmares than do healthy controls. We also hypothesized that both MSP and nightmares/bad dreams are associated with increased anxiety and depression symptoms, low serum vitamin D levels, and decreased daily calcium intake. If study results support our hypothesis, then treatment of MSP, anxiety, depression, and vitamin D deficiency and increasing daily calcium intake should be recommended for the prevention of bad dreams and nightmares.

\section{Materials and Methods}

\section{Study design and participants}

This is a case-control study, which involved 191 outpatients with MSP and 191 age/gender matched healthy controls with no pain or general weakness of both genders.
Cases were recruited from patients attending physical therapy clinics, neurology clinics, the radiology department, and urology outpatient clinics at King Abdullah University Teaching Hospital (KAUH), Irbid, Jordan and through advertising the project on the Jordan University of Science \& Technology (JUST), Irbid, Jordan. Healthy controls with no MSP or general weakness, who were visiting different clinics for check-ups or as accompanying persons as well as visiting the university campus, were also recruited. The research was conducted according to the declaration of Helsinki and was approved by the Institutional Review Board Committee of KAUH and JUST (Ref No. 49/132/2020, date 01.04.2020). Written informed consents were obtained from all participants prior to participation. Patients with chronic or acute medical conditions, patients who did not answer all parts of the questionnaires, and patients who have been on vitamin D supplements for the past 2 months were excluded from the study.

\section{Data collection}

All participants were instructed to complete self-assessment questionnaires including their demographics (age, gender, marital status, height, and weight) and whether they experience MSP during the past month or not. The self-assessment questionnaires included also a question about the most frequent type of their dreams (normal dreams, bad dreams, or nightmares) during the past month. Normal dreams were defined as those dreams that do not disturb sleep. According to current diagnostic classifications, nightmares are defined as frightening or disturbing dreams that awaken the sleeper while bad dreams are defined as frightening or disturbing dreams that do not awaken the sleeper (Hasler \& Germain, 2009; Nadorff et al., 2014). However, in the current study, we combined participants with bad dreams and participants with nightmares in one group since there was only very limited number of participants who reported nightmares. This group included participants with frightening or disturbing dreams that may or may not awaken the sleeper.

\section{Assessment of daily calcium intake}

Daily calcium intake was determined as previously described (Alkhatatbeh, Abdul-Razzak, \& Khwaileh, 2021). In brief, participants were asked questions regarding their daily frequency and type of dairy products intake (milk, yogurt, cheddar cheese, cream cheese, and labaneh, which is a soft cream cheese made by removing whey from yogurt with a cheese cloth). Intake of dairy products was determined on a daily basis as none, one, two, or three or more dairy servings per day (Alkhatatbeh et al., 2021). On the assessment, a dairy serving was defined as: 1 cup of milk or yogurt (300 mg calcium), 2 full tablespoons $(28 \mathrm{~g})$ of labaneh (100 $\mathrm{mg}$ calcium), and a $28 \mathrm{~g}$ piece of cheese $(162 \mathrm{mg}$ calcium) or cream cheese $(20 \mathrm{mg}$ calcium) (Alkhatatbeh et al., 2021). 


\section{Determination of serum 25-hydroxyvitamin D concentration}

Serum was prepared from fresh venous blood samples by centrifugation at 2,100 $\mathrm{g}$ for $8 \mathrm{~min}$ at room temperature using a high speed Jouan centrifuge (Thermo Fisher Scientific, Inc., Waltham, MA, USA). Then, concentration of 25-hydroxyvitamin D was measured by electrochemiluminescence immunoassay using Roche Modular E170 Analyzer (Roche Diagnostics, Basel, Switzerland). Participants were classified according to their serum 25-hydroxyvitamin D into normal vitamin D levels $(\geq 30$ $\mathrm{ng} / \mathrm{mL})$, insufficient vitamin D levels $(20-30 \mathrm{ng} / \mathrm{mL})$, deficient vitamin D levels (10-20 ng/mL), or severely deficient $(<10 \mathrm{ng} / \mathrm{mL})$ (Holick, 2009).

\section{Assessment of anxiety and depression symptoms}

Anxiety and depression symptoms were assessed using an Arabic translation (Alkhatatbeh et al., 2021) of the Hospital Anxiety and Depression Scale (HADS) (Zigmond \& Snaith, 1983). The HADS consists of 7 items that assess anxiety symptoms and other 7 items that assess depression symptoms. Each item has a 0 to 3 symptom severity scale, with a maximum score of 21 for anxiety and for depression. Participants were categorized as normal (scores from 0 to 7), borderline (scores from 8-10) or abnormal (scores from 11-21) (Zigmond \& Snaith, 1983).

\section{Statistical analyses}

IBM SPSS Statistics for Windows, version 20 (IBM Corp., Armonk, NY, USA) was used to statistically analyse the data (Gouda, 2015). Frequencies and percentages were calculated for categorical variables, and medians $\left(25^{\text {th }}-75^{\text {th }}\right.$ percentiles) were calculated for continuous variables that were not normally distributed. Differences in categorical variables between groups (i.e., participants with MSP vs healthy controls and participants with history of normal dreams vs participants with history of bad dreams and nightmares) were examined using Chi square test. Differences in continuous variables between groups (i.e., participants with MSP vs healthy controls and participants with history of normal dreams $v s$ participants with history of bad dreams and nightmares) were examined using the nonparametric MannWhitney $\mathrm{U}$ test. Binary logistic regression analysis was used to identify the predictors MSP (dependent variable: MSP vs healthy controls) and predictors of bad dreams and nightmares (dependent variable: bad dreams and nightmares $v s$ normal dreams). All the tests were 2-tailed, and results with $\mathrm{P}<0.05$ were considered statistically significant.

\section{Results}

\section{General characteristics of participants}

Participants were 191 individuals with chronic multisite MSP and 191 age and gender matched healthy controls.
The majority were women (64.9\%) and married (56\%). The mean (SD) age for the sample was 33.10 (11.87) years. As shown in Table 1, there was no significant difference in age, gender, or marital status between participants with chronic multisite MSP and healthy controls.

\section{History of dreams among participants during the past month}

Some $70.9 \%(n=271)$ of participants had reported normal dreams while $29.1 \%(n=111)$ of participants had reported bad dreams or nightmares during the past month (Table 1). Bad dreams and nightmares frequency among the case and controls was as follows: $44 \%(n=84)$ of the cases had bad dreams and only $3.1 \%(n=6)$ of them had nightmares, compared to $7.3 \%(\mathrm{n}=14)$ and $3.7 \%(\mathrm{n}=7)$ of the controls, respectively $(\mathrm{P}<0.001)$.

More women (73\%) than men $(27 \%)$ reported to have disturbing dreams among study population.

\section{Vitamin D status among participants}

The median $\left(25^{\text {th }}-75^{\text {th }}\right.$ quartiles $)$ serum 25 -hydroxyvitamin D was $13.23(7.59-23.43) \mathrm{ng} / \mathrm{mL}$. Only 14.7\% $(\mathrm{n}=56)$ of participants had normal serum 25-hydroxyvitamin D levels ( $\geq 30 \mathrm{ng} / \mathrm{mL})$. While, $17.8 \%(\mathrm{n}=68), 32.2 \%$ $(n=123)$, and $35.3 \%(n=135)$ of participants had insufficient (20-30 ng/mL), deficient (10-20 ng/mL), and severely deficient $(<10 \mathrm{ng} / \mathrm{mL})$ serum 25 -hydroxyvitamin D levels.

\section{Status of daily calcium intake among participants}

The median $\left(25^{\text {th }}-75^{\text {th }}\right.$ quartiles $)$ of estimated daily calcium intake was 369.50 (174.80-584.01) mg/day. 95.29\% $(n=364)$ of participants had reported daily calcium intake below the recommended daily allowance of $<1000$ $\mathrm{mg} /$ day (Lima et al., 2016).

\section{Status of anxiety and depression symptoms among participants}

The median $\left(25^{\text {th }}-75^{\text {th }}\right.$ quartiles $)$ of HADS-anxiety scores was 7 (4-11). 28.8\% $(n=110), 13.9 \%(n=53)$, and $57.3 \%(n=219)$ of participants had abnormal, borderline, and normal HADS- anxiety scores, respectively. The median $\left(25^{\text {th }}-75^{\text {th }}\right.$ quartiles $)$ of HADS- depression scores was 7 (4-10). 21.5\% $(\mathrm{n}=82), 20.7 \%(\mathrm{n}=79)$, and $57.9 \%$ $(n=221)$ of participants had abnormal, borderline, and normal HADS- depression scores, respectively.

\section{Differences in study variables between participants with and without musculoskeletal pain (case-control)}

As shown in Table 1, participants with MSP had significantly lower serum 25-hydroxyvitamin D levels and lower daily calcium intake compared to healthy controls $(\mathrm{Ps}<0.001)$. Higher percentage of participants with MSP had deficient (37.7\% vs 26.7\%) and severely deficient 
(45.5\% vs 25.1\%) vitamin D status compared to healthy controls $(\mathrm{P}<0.001)$. As well, lower percentage of participants with MSP had daily calcium intake of more than $484 \mathrm{mg} /$ day compared to healthy controls $(18.8 \%$ vs $47.6 \%$, respectively, $\mathrm{P}<0.001$ ). Participants with MSP had also higher HADS-anxiety and depression scores compared to healthy controls $\left(\mathrm{Ps}_{\mathrm{s}}<0.001\right)$. Higher percentage of participants with MSP had abnormal HADS-anxiety (50.3\% vs $7.3 \%$ ) and depression (38.2\% vs $4.7 \%)$ scores compared to healthy controls $(\mathrm{Ps}<0.001)$. Higher percentages of participants with MSP had bad dreams and nightmares during the past month compared to healthy controls (47.1\% vs $11 \%, \mathrm{P}<0.001)$. In contrast, there was no significant difference in age, gender, and marital status between participants with MSP and healthy controls $(\mathrm{Ps}>0.05)$.

\section{Differences in study variables between participants with normal dreams and participants with bad dreams and nightmares}

As shown in Table 2, participants with bad dreams and nightmare were significantly younger in age compared to participants with normal dreams $(\mathrm{P}<0.01) .73 \%(\mathrm{n}=81)$ of participants with bad dreams and nightmare were females compared to $61.6 \%(n=167)$ of participants with normal dreams $(\mathrm{P}=0.04) .58 .6 \%(\mathrm{n}=65)$ of participants with bad dreams and nightmares dreams were single compared to $38 \% \quad(n=103)$ of participants with normal dreams $(\mathrm{P}<0.001)$. Participants with bad dreams and nightmares had significantly lower serum 25-hydroxyvitamin D levels $(\mathrm{P}<0.01)$ and daily calcium intake $(\mathrm{P}<0.001)$ compared to participants with normal dreams. $37.8 \%(\mathrm{n}=42)$ and $42.3 \%(n=47)$ of participants with bad dreams and

Table 1. Differences in variables between participants with and without musculoskeletal pain.

\begin{tabular}{|c|c|c|c|c|c|}
\hline Variable & $\begin{array}{c}\text { Total } \\
(\mathrm{n}=\mathbf{3 8 2})\end{array}$ & $\begin{array}{l}\text { Healthy controls } \\
\qquad(\mathrm{n}=191)\end{array}$ & $\begin{array}{c}\text { Cases } \\
(n=191)\end{array}$ & $\begin{array}{c}\text { Group difference } \\
\text { statistic }\end{array}$ & $\mathbf{P}$ \\
\hline \multicolumn{6}{|l|}{ Age categories } \\
\hline$<30$ years & $189(49.5)$ & $96(50.3)$ & $93(48.7)$ & \multirow{3}{*}{$\circ$} & \multirow{3}{*}{0.79} \\
\hline $30-40$ years & $99(25.9)$ & $51(26.7)$ & $48(25.1)$ & & \\
\hline$>40$ years & $94(24.6)$ & $44(23)$ & $50(26.2)$ & & \\
\hline \multicolumn{6}{|l|}{ Gender } \\
\hline Male & $134(35.1)$ & $67(35.1)$ & $67(35.1)$ & \multirow{2}{*}{$\circ$} & \multirow{2}{*}{1.00} \\
\hline Female & $248(64.9)$ & $124(64.9)$ & $124(64.9)$ & & \\
\hline \multicolumn{6}{|l|}{ Marital status } \\
\hline Single & $168(44)$ & $76(39.8)$ & $92(48.2)$ & \multirow{2}{*}{$\circ$} & \multirow{2}{*}{0.12} \\
\hline Married & $214(56)$ & $115(60.2)$ & $99(51.8)$ & & \\
\hline \multicolumn{6}{|l|}{ History of dreams during the past month } \\
\hline Normal dreams & $271(70.9)$ & $170(89)$ & $101(52.9)$ & \multirow{2}{*}{$\circ$} & \multirow{2}{*}{$<0.001$} \\
\hline Bad dreams and nightmares & $111(29.1)$ & $21(11)$ & $90(47.1)$ & & \\
\hline 25-hydroxyvitamin D (ng/mL) & $13.23(7.59-23.43)$ & $19.67(9.99-30.0)$ & $10.23(6.0-16.22)$ & $*$ & $<0.001$ \\
\hline \multicolumn{6}{|l|}{ Vitamin D status } \\
\hline Normal ( $\geq 30 \mathrm{ng} / \mathrm{mL})$ & $56(14.7)$ & $49(25.7)$ & $7(3.7)$ & \multirow{4}{*}{$\circ$} & \multirow{4}{*}{$<0.001$} \\
\hline Insufficient (20-30 ng/mL) & $68(17.8)$ & $43(22.5)$ & $25(13.1)$ & & \\
\hline Deficient $(10-20 \mathrm{ng} / \mathrm{mL})$ & $123(32.2)$ & $51(26.7)$ & $72(37.7)$ & & \\
\hline Severely deficient $(<10 \mathrm{ng} / \mathrm{mL})$ & $135(35.3)$ & $48(25.1)$ & $87(45.5)$ & & \\
\hline Daily calcium intake (mg/day) & $369.50(174.80-584.01)$ & $470.56(300.0-700.0)$ & $250(107.14-432.0)$ & $*$ & $<0.001$ \\
\hline \multicolumn{6}{|l|}{ Daily calcium intake (mg/day) } \\
\hline$<230 \mathrm{mg} /$ day & $127(33.2)$ & $32(16.8)$ & $95(49.7)$ & \multirow{3}{*}{$\circ$} & \multirow{3}{*}{$<0.001$} \\
\hline 230-484 mg/day & $128(33.5)$ & $68(35.6)$ & $60(31.4)$ & & \\
\hline$>484 \mathrm{mg} /$ day & $127(33.2)$ & $91(47.6)$ & $36(18.8)$ & & \\
\hline HADS-anxiety score (0-21) & $7(4-11)$ & $5(3-7)$ & $11(7-14)$ & $*$ & $<0.001$ \\
\hline \multicolumn{6}{|l|}{ HADS-anxiety score $(0-21)$} \\
\hline Normal $(0-7)$ & $219(57.3)$ & $160(83.8)$ & $59(30.9)$ & \multirow{3}{*}{$\circ$} & \multirow{3}{*}{$<0.001$} \\
\hline Borderline (8-10) & $53(13.9)$ & $17(8.9)$ & $36(18.8)$ & & \\
\hline Abnormal (11-21) & $110(28.8)$ & $14(7.3)$ & $96(50.3)$ & & \\
\hline HADS-depression score & $7(4-10)$ & $5(3-7)$ & $9(6-12)$ & $*$ & $<0.001$ \\
\hline \multicolumn{6}{|l|}{ HADS-depression score (0-21) } \\
\hline Normal $(0-7)$ & $221(57.9)$ & $155(81.2)$ & $66(34.6)$ & \multirow{3}{*}{$\circ$} & \multirow{3}{*}{$<0.001$} \\
\hline Borderline (8-10) & $79(20.7)$ & $27(14.1)$ & $52(27.2)$ & & \\
\hline Abnormal (11-21) & $82(21.5)$ & $9(4.7)$ & $73(38.2)$ & & \\
\hline
\end{tabular}

*Mann Whitney U test; ${ }^{\circ} \mathrm{Chi}$-square test. ( $\mathrm{P}<0.05$ was considered statistically significant). Data are presented as frequency $(\%)$ or median $\left(25^{\text {th }}-75^{\text {th }}\right.$ percentiles). HADS, Hospital Anxiety and Depression Scale. 
nightmares had deficient and severely deficient serum vitamin D levels compared to $29.9 \%(\mathrm{n}=81)$ and $32.5 \%$ $(\mathrm{n}=88)$, respectively compared to participants with normal dreams $(\mathrm{P}=0.01) .18 .9 \%(\mathrm{n}=21)$ of participants with bad dreams and nightmares had daily calcium intake of more than $484 \mathrm{mg} /$ day compared to $39.1 \%(\mathrm{n}=106)$ of participants with normal dreams $(\mathrm{P}<0.001)$. Participants with bad dreams and nightmares had significantly higher HADS-anxiety and depression scores compared to participants with normal dreams (Ps<0.001). 61.3\% ( $\mathrm{n}=68)$ of participants with bad dreams and nightmares had abnormal HADS- anxiety scores compared to $15.5 \%(\mathrm{n}=42)$ of participants with normal dreams $(\mathrm{P}<0.001) .47 .7 \%(\mathrm{n}=53)$ of participants with bad dreams and nightmares had abnormal HADS- depression scores compared to $10.7 \%$ $(\mathrm{n}=29)$ of participants with normal dreams $(\mathrm{P}<0.001)$.

\section{Predictors of musculoskeletal pain among study participants}

Binary logistic regression analysis (Table 3 , model 1) showed that MSP can be predicted from, borderline $(\mathrm{OR}=5.43, \mathrm{P}<0.001)$ and abnormal $(\mathrm{OR}=13.54, \mathrm{P}<0.001)$ HADS-anxiety scores, insufficient $(\mathrm{OR}=3.91, \mathrm{P}=0.01)$, deficient $(\mathrm{OR}=6.61, \mathrm{P}<0.001)$, and severely deficient $(\mathrm{OR}=6.31, \mathrm{P}<0.001)$ serum 25-hydroxyvitamin $\mathrm{D}$ levels, and levels of daily calcium intake below $230 \mathrm{mg}$ /day $(\mathrm{OR}=4.40, \mathrm{P}<0.001)$. Binary logistic regression analysis (Table 3, model 2) showed that MSP can be predicted from, borderline $(\mathrm{OR}=5.33, \mathrm{P}<0.001)$ and abnormal $(\mathrm{OR}=16.85$, $\mathrm{P}<0.001)$ HADS-depression scores, insufficient $(\mathrm{OR}=3.07$, $\mathrm{P}<0.05)$, deficient $(\mathrm{OR}=8.89, \mathrm{P}<0.001)$, and severely deficient $(\mathrm{OR}=8.77, \mathrm{P}<0.001)$ serum 25-hydroxyvitamin $\mathrm{D}$ levels, and levels of daily calcium intake below $230 \mathrm{mg} /$ day

Table 2. Differences in variables between participants with normal dreams and participants with bad dreams or nightmares.

\begin{tabular}{|c|c|c|c|c|}
\hline Variable & $\begin{array}{l}\text { Participants with history } \\
\text { of normal dreams } \\
(n=271)\end{array}$ & $\begin{array}{c}\text { Participants with history } \\
\text { of bad dreams and nightmares } \\
(n=111)\end{array}$ & Group difference statistic & $\mathbf{P}$ \\
\hline Age (years) & $30(24-42)$ & $26(22-37)$ & $*$ & $<0.01$ \\
\hline $\begin{array}{l}\text { Age categories } \\
<30 \text { years } \\
30-40 \text { years } \\
>40 \text { years }\end{array}$ & $\begin{array}{l}121(44.6) \\
77(28.4) \\
73(26.9)\end{array}$ & $\begin{array}{l}68(61.3) \\
22(19.8) \\
21(18.9)\end{array}$ & $\circ$ & 0.01 \\
\hline $\begin{array}{l}\text { Gender } \\
\text { Male } \\
\text { Female }\end{array}$ & $\begin{array}{l}104(38.4) \\
167(61.6)\end{array}$ & $\begin{array}{l}30(27) \\
81(73)\end{array}$ & $\circ$ & 0.04 \\
\hline $\begin{array}{l}\text { Marital status } \\
\text { Single } \\
\text { Married } \\
\end{array}$ & $\begin{array}{l}103(38) \\
168(62)\end{array}$ & $\begin{array}{l}65(58.6) \\
46(41.4) \\
\end{array}$ & $\circ$ & $<0.001$ \\
\hline 25-hydroxyvitamin D (ng/mL) & $15.21(8.40-26.28)$ & $11.26(6.0-17.72)$ & $*$ & $<0.01$ \\
\hline $\begin{array}{l}\text { Vitamin D status } \\
\text { Normal }(\geq 30 \mathrm{ng} / \mathrm{mL}) \\
\text { Insufficient }(20-30 \mathrm{ng} / \mathrm{mL}) \\
\text { Deficient }(10-20 \mathrm{ng} / \mathrm{mL}) \\
\text { Severely deficient }(<10 \mathrm{ng} / \mathrm{mL})\end{array}$ & $\begin{array}{l}47(17.3) \\
55(20.3) \\
81(29.9) \\
88(32.5)\end{array}$ & $\begin{array}{c}9(8.1) \\
13(11.7) \\
42(37.8) \\
47(42.3)\end{array}$ & $\circ$ & 0.01 \\
\hline Daily calcium intake (mg/day) & $409.68(223.0-625.40)$ & $223.69(96.28-455.14)$ & $*$ & $<0.001$ \\
\hline $\begin{array}{l}\text { Daily calcium intake (mg/day) } \\
<230 \mathrm{mg} / \text { day } \\
230-484 \mathrm{mg} / \text { day } \\
>484 \mathrm{mg} / \text { day }\end{array}$ & $\begin{array}{c}70(25.8) \\
95(35.1) \\
106(39.1)\end{array}$ & $\begin{array}{l}57(51.4) \\
33(29.7) \\
21(18.9)\end{array}$ & $\circ$ & $<0.001$ \\
\hline HADS-anxiety score (0-21) & $5(3-8)$ & $12(8-16)$ & $*$ & $<0.001$ \\
\hline $\begin{array}{l}\text { HADS-anxiety score (0-21) } \\
\text { Normal }(0-7) \\
\text { Borderline }(8-10) \\
\text { Abnormal }(11-21)\end{array}$ & $\begin{array}{l}194(71.6) \\
35(12.9) \\
42(15.5)\end{array}$ & $\begin{array}{l}25(22.5) \\
18(16.2) \\
68(61.3)\end{array}$ & $\circ$ & - \\
\hline HADS-depression score & $6(4-9)$ & $10(6-13)$ & $*$ & $<0.001$ \\
\hline $\begin{array}{l}\text { HADS-depression score (0-21) } \\
\text { Normal }(0-7) \\
\text { Borderline }(8-10) \\
\text { Abnormal }(11-21)\end{array}$ & $\begin{array}{l}187(69) \\
55(20.3) \\
29(10.7)\end{array}$ & $\begin{array}{l}34(30.6) \\
24(21.6) \\
53(47.7)\end{array}$ & $\circ$ & $<0.001$ \\
\hline
\end{tabular}


$(\mathrm{OR}=5.08, \mathrm{P}<0.001)$ and levels of daily calcium intake between 230 and $484 \mathrm{mg} /$ day $(\mathrm{OR}=1.97, \mathrm{P}=0.03)$.

\section{Predictors of bad dreams and nightmares among study participants}

Binary logistic regression analysis (Table 4, model 1) showed that bad dreams and nightmares can be predicted from MSP $(\mathrm{OR}=3.07, \mathrm{P}<0.01)$, borderline $(\mathrm{OR}=2.94$, $\mathrm{P}<0.01)$ and abnormal $(\mathrm{OR}=6.20, \mathrm{P}<0.001)$. HADS-anxiety scores, and abnormal HADS- depression scores $(\mathrm{OR}=2.87, \mathrm{P}=0.01)$. Binary logistic regression analysis (Table 4, model 2) showed that bad dreams and nightmares can be predicted from MSP $(\mathrm{OR}=3.79, \mathrm{P}<0.001)$, younger age $(\mathrm{OR}=-0.03, \mathrm{P}=0.03)$, and abnormal HADSdepression scores $(\mathrm{OR}=5.40, \mathrm{P}<0.001)$.

\section{Discussion}

The aim of the current study was to test the hypothesis that participants with MSP have significantly more bad dreams and nightmares than do healthy controls and also to test the hypothesis that both MSP and nightmares/bad dreams are associated with increased anxiety and depression symptoms, low serum vitamin D levels, and decreased daily calcium intake.
In accordance with our hypotheses, we found that patients with MSP had significantly higher prevalence of bad dreams and nightmares, vitamin D deficiency, low daily calcium intake and scored higher for psychological symptoms compared to healthy controls.

Anxiety, depression symptoms and MSP were predictors for bad dreams and nightmares.

Vitamin D is a fat-soluble vitamin suggested to play both a direct and an indirect role in the regulation of sleep. It exerts its physiological functions through binding to the vitamin $\mathrm{D}$ receptors in many cell types including those in gut, bone, skeletal muscle and brain. Vitamin D plays a critical role in the regulation of calcium and phosphate hemostasis (Gureje et al., 2008). Inadequate vitamin D level leads to the classic diseases of bone demineralization and MSP (McCarty, Chesson, Jain, \& Marino, 2014). In addition, it has been suggested that vitamin $\mathrm{D}$ is also involved in the pathways of production of melatonin, the hormone involved in the regulation of human circadian rhythms and sleep thus it may disrupt sleep and directly cause daytime impairment (Romano et al., 2020). In addition to its classical function in calcium and phosphate homeostasis, there is evidence suggesting that vitamin D plays an important role in brain and nervous system health through maintaining calcium hemostasis in brain (AbdulRazzak, Mayyas, et al., 2018). Dysregulation of $\mathrm{Ca}^{+2}$

Table 3. Predictors of musculoskeletal pain.

\begin{tabular}{|c|c|c|c|c|c|}
\hline Variable & Value & B (SE) & $\begin{array}{c}\text { Model } 1 \\
\text { OR }\end{array}$ & Confidence interval & $\mathbf{P}^{*}$ \\
\hline Constant & $0^{0}$ & $-3.14(0.51)$ & 0.04 & - & $<0.001$ \\
\hline \multirow[t]{3}{*}{ HADS-anxiety score } & Normal (Reference) & & & & \\
\hline & Borderline & $1.69(0.37)$ & 5.43 & $2.64-11.14$ & $<0.001$ \\
\hline & Abnormal & $2.61(0.35)$ & 13.54 & $6.86-26.72$ & $<0.001$ \\
\hline \multirow[t]{4}{*}{ Serum 25-hydroxyvitamin $\mathrm{D}(\mathrm{ng} / \mathrm{mL})$} & Normal (Reference) & & & & \\
\hline & Insufficient & $1.36(0.55)$ & 3.91 & $1.33-11.46$ & 0.01 \\
\hline & Deficient & $1.89(0.51)$ & 6.61 & $2.41-18.09$ & $<0.001$ \\
\hline & Severely deficient & $1.84(0.52)$ & 6.31 & $2.30-17.30$ & $<0.001$ \\
\hline \multirow[t]{3}{*}{ Dairy calcium intake (mg/day) } & $<230 \mathrm{mg} /$ day & $1.48(0.34)$ & 4.40 & $2.28-8.50$ & $<0.001$ \\
\hline & $230-484 \mathrm{mg} /$ day & $0.60(0.32)$ & 1.83 & $0.98-3.41$ & 0.06 \\
\hline & $>484$ mg/day (Reference) & & & & \\
\hline & & & Model 2 & & \\
\hline Variable & Value & B (SE) & OR & Confidence interval & $P^{*}$ \\
\hline Constant & - & $-3.36(0.53)$ & 0.04 & - & $<0.001$ \\
\hline \multirow[t]{3}{*}{ HADS-depression score } & Normal (Reference) & & & & \\
\hline & Borderline & $1.67(0.32)$ & 5.33 & $2.84-10.01$ & $<0.001$ \\
\hline & Abnormal & $2.83(0.42)$ & 16.85 & $7.43-38.21$ & $<0.001$ \\
\hline \multirow[t]{4}{*}{ Serum 25-hydroxyvitamin D (ng/mL) } & Normal (Reference) & & & & \\
\hline & Insufficient & $1.12(0.56)$ & 3.07 & $1.02-9.21$ & $<0.05$ \\
\hline & Deficient & $2.18(0.53)$ & 8.89 & $3.17-24.89$ & $<0.001$ \\
\hline & Severely deficient & $2.17(0.52)$ & 8.77 & $3.14-24.51$ & $<0.001$ \\
\hline \multirow[t]{3}{*}{ Dairy calcium intake (mg/day) } & $<230 \mathrm{mg} /$ day & $1.63(0.34)$ & 5.08 & $2.64-9.81$ & $<0.001$ \\
\hline & $230-484 \mathrm{mg} /$ day & $0.68(0.32)$ & 1.97 & $1.06-3.69$ & 0.03 \\
\hline & $>484$ mg/day (Reference) & & & & \\
\hline
\end{tabular}

*Binary logistic regression (dependent variable: musculoskeletal pain $v$ S Controls), $\mathrm{P}<0.05$ was considered statistically significant. B, coefficient (intercept); SE, standard error; OR, odds ratio; HADS, Hospital Anxiety and Depression Scale. 
homeostasis can influence neuron excitability, which in turn affects network activity, metabolism, and increases the risk factors for psychiatric diseases including depression (Zündorf \& Reiser, 2011). Chronic pain is often associated with poor sleep quality. Ashworth et al. reported that poor sleepers with chronic pain were younger and reported more pain, depression, pain-related anxiety (Ashworth, Davidson, \& Espie, 2010).

In our previous cross sectional study that involve 1422 students' ages between 18-29 years, poor sleep quality was reported by $62.66 \%$ of the participants (Alkhatatbeh et al., 2021). In addition, the participants with poor sleep quality reported lower daily calcium intake, higher anxiety and depression levels, more severe MSP. Anxiety, depression, low calcium intake, and MSP were significant predictors of poor sleep quality (Alkhatatbeh et al., 2021).

In the current study, individuals with MSP with bad dreams and nightmares have higher prevalence of vitamin D deficiency, were more anxious, depressed, and low daily dietary calcium intake compared to controls. Anxiety, depression symptoms and MSP were predictors for bad dreams and nightmares.

Table 4. Predictors of bad dreams and nightmares.

\begin{tabular}{|c|c|c|c|c|c|}
\hline Variable & Value & B (SE) & $\begin{array}{c}\text { Model } 1 \\
\text { OR }\end{array}$ & Confidence interval & $\mathbf{P}^{*}$ \\
\hline Constant & - & $-1.94(0.83)$ & 0.14 & - & 0.02 \\
\hline Age (years) & - & $-0.02(0.02)$ & 0.99 & $0.96-1.01$ & 0.30 \\
\hline Gender & $\begin{array}{l}\text { Male (Reference) } \\
\text { Female }\end{array}$ & $-0.10(0.33)$ & 0.90 & $0.48-1.72$ & 0.76 \\
\hline Marital status & $\begin{array}{l}\text { Married (Reference) } \\
\text { Single }\end{array}$ & $0.55(0.32)$ & 1.72 & $0.93-3.20$ & 0.09 \\
\hline MSP & $\begin{array}{l}\text { No (Reference) } \\
\text { Yes }\end{array}$ & $1.12(0.36)$ & 3.07 & $1.52-6.20$ & $<0.01$ \\
\hline HADS-anxiety score & $\begin{array}{l}\text { Normal (Reference) } \\
\text { Borderline } \\
\text { Abnormal }\end{array}$ & $\begin{array}{l}1.08(0.40) \\
1.82(0.34)\end{array}$ & $\begin{array}{l}2.94 \\
6.20\end{array}$ & $\begin{array}{c}1.35-6.41 \\
3.16-12.16\end{array}$ & $\begin{array}{l}<0.01 \\
<0.001\end{array}$ \\
\hline Serum 25-hydroxyvitamin $\mathrm{D}(\mathrm{ng} / \mathrm{mL})$ & $\begin{array}{l}\text { Normal (Reference) } \\
\text { Insufficient } \\
\text { Deficient } \\
\text { Severely deficient }\end{array}$ & $\begin{array}{l}-0.51(0.57) \\
-0.29(0.51) \\
-0.55(0.52)\end{array}$ & $\begin{array}{l}0.60 \\
0.75 \\
0.58\end{array}$ & $\begin{array}{l}0.20-1.86 \\
0.28-2.04 \\
0.21-1.61\end{array}$ & $\begin{array}{l}0.38 \\
0.57 \\
0.30\end{array}$ \\
\hline Dairy calcium intake (mg/day) & $\begin{array}{l}<230 \mathrm{mg} / \text { day } \\
230-484 \mathrm{mg} / \text { day } \\
>484 \mathrm{mg} / \text { day (Reference) }\end{array}$ & $\begin{array}{l}0.51(0.37) \\
0.09(0.37)\end{array}$ & $\begin{array}{l}1.66 \\
1.10\end{array}$ & $\begin{array}{l}0.81-3.41 \\
0.54-2.24\end{array}$ & $\begin{array}{l}0.17 \\
0.80\end{array}$ \\
\hline Variable & Value & B (SE) & $\begin{array}{c}\text { Model } 2 \\
\text { OR }\end{array}$ & Confidence interval & $\mathbf{P}^{*}$ \\
\hline Constant & - & $-1.08(0.82)$ & 0.34 & - & 0.19 \\
\hline Age (years) & - & $-0.03(0.02)$ & 0.97 & $0.94-1.00$ & 0.03 \\
\hline Gender & $\begin{array}{l}\text { Male (Reference) } \\
\text { Female }\end{array}$ & $-0.16(0.33)$ & 0.86 & $0.45-1.63$ & 0.64 \\
\hline Marital status & $\begin{array}{l}\text { Married (Reference) } \\
\text { Single }\end{array}$ & $0.40(0.31)$ & 1.49 & $0.81-2.73$ & 0.20 \\
\hline MSP & $\begin{array}{l}\text { No (Reference) } \\
\text { Yes }\end{array}$ & $1.33(0.35)$ & 3.79 & $1.92-7.46$ & $<0.001$ \\
\hline HADS-depression score & $\begin{array}{l}\text { Normal (Reference) } \\
\text { Borderline } \\
\text { Abnormal }\end{array}$ & $\begin{array}{l}0.48(0.34) \\
1.69(0.35)\end{array}$ & $\begin{array}{l}1.62 \\
5.40\end{array}$ & $\begin{array}{c}0.82-3.17 \\
2.71-10.76\end{array}$ & $\begin{array}{l}0.16 \\
<0.001\end{array}$ \\
\hline Serum 25-hydroxyvitamin $\mathrm{D}(\mathrm{ng} / \mathrm{mL})$ & $\begin{array}{l}\text { Normal (Reference) } \\
\text { Insufficient } \\
\text { Deficient } \\
\text { Severely deficient }\end{array}$ & $\begin{array}{l}-0.78(0.57) \\
-0.24(0.50) \\
-0.47(0.51)\end{array}$ & $\begin{array}{l}0.46 \\
0.78 \\
0.63\end{array}$ & $\begin{array}{l}0.15-1.41 \\
0.29-2.10 \\
0.23-1.71\end{array}$ & $\begin{array}{l}0.17 \\
0.63 \\
0.36\end{array}$ \\
\hline Dairy calcium intake (mg/day) & $\begin{array}{l}<230 \mathrm{mg} / \text { day } \\
230-484 \mathrm{mg} / \text { day } \\
>484 \mathrm{mg} / \text { day (Reference) }\end{array}$ & $\begin{array}{l}0.52(0.36) \\
0.05(0.36)\end{array}$ & $\begin{array}{l}1.68 \\
1.05\end{array}$ & $\begin{array}{l}0.83-3.41 \\
0.52-2.13\end{array}$ & $\begin{array}{l}0.15 \\
0.90\end{array}$ \\
\hline
\end{tabular}

*Binary logistic regression (dependent variable: musculoskeletal pain $v$ S Controls), $\mathrm{P}<0.05$ was considered statistically significant. B, coefficient (intercept); SE, standard error; OR, odds ratio; HADS, Hospital Anxiety and Depression Scale; MSP, musculoskeletal pain. 
Our findings about the association between bad dreams and nightmares with psychological symptoms concur with the results of previously published studies in sleep disorders (Ohayon et al., 1997; Spoormaker, Schredl, \& van den Bout, 2006), anxiety and depression disorders, and many different types of psychopathy (Lemyre et al., 2019; Levin \& Fireman, 2002; Swart et al., 2013).

Together, the findings of this study suggest that vitamin D deficiency, chronic MSP, and low dietary calcium intake may be predisposing developmental factors for pain related psychological symptoms and thus bad dreams and nightmares.

Our findings indicate that individuals with MSP and related psychological symptoms have greater risk of having bad dreams and nightmares than individuals with no MSP.

More women than men reported to have disturbing dreams, which is consistent with a previously published report (Krystal, 2012).

Previously (Abdul-Razzak, Almanasrah, et al., 2018; Abdul-Razzak et al., 2019; Abdul-Razzak, Mayyas, et al., 2018) vitamin D supplementation plus increased dairyproduct intake resulted in significant reduction in MSP sites and severity, which was accompanied by significant reduction in anxiety and depression scores were observed. Thus, vitamin D and calcium may represent a safe and cheap interventional therapy for the target population.

This study has some strengths including its suitable sample size, design, and inclusion of serum vitamin D as a potential biomarker of psychologic symptoms. There were several limitations to the current study that may affect findings. A validated measure of dreams and nightmares was not used; types of dreams were determined by self-assessment. Some people do not remember dreams or are not aware of them. Also, classification of dreams may differ from one person to another. In addition, feeling musculoskeletal pain could affect the quality of the dream, causing disturbing night rest, which also may affect the self-classification of dreams. In addition, we did not ask participants if they were using any current medication that may be a potential confounding factor on bad dreams and nightmares. Because individuals with chronic or acute medical conditions were excluded from the study, we assumed that such individuals do not use regular medications. Also, we did not ask participants about trauma history, which could also be a potential confounding factor on bad dreams and nightmares. Despite these limitations, our findings provide evidence of the relationship between MSP, dreaming, vitamin D, and calcium and may encourage further researchers to further investigate the relationship among these variables.

\section{Conclusions}

In accordance with our hypothesis, we found a high prevalence of vitamin D deficiency and low daily calcium intake among patients who experienced MSP. In addition, patients with bad dreams and nightmares scored higher for anxiety and depression symptoms compared to controls. Anxiety, depression and MSP were all independent predictors for bad dreams and nightmares. In terms of clinical relevance of our findings, screening individuals with disturbing dreams for MSP, vitamin D deficiency, low daily calcium intake and psychological symptoms is suggested to be considered as part of evaluation of individuals with disturbing dreams.

\section{References}

Abdul-Razzak, K. K., Almanasrah, S. O., Obeidat, B. A., \& Khasawneh, A. G. (2018). Vitamin D is a potential antidepressant in psychiatric outpatients. International Journal of Clinical Pharmacology and Therapy, 56(12), 585-596. doi: 10.5414/cp203309.

Abdul-Razzak, K. K., Alshogran, O. Y., Altawalbeh, S. M., AlGhalayini, I. F., Al-Ghazo, M. A., Alazab, R. S., ... \&Sahawneh, F. E. (2019). Overactive bladder and associated psychological symptoms: A possible link to vitamin D and calcium. Neurourology and Urodynamic, 38(4), 1160-1167. doi: 10.1002/nau.23975.

Abdul-Razzak, K. K., Mayyas, F. A., \& Al-Farras, M. I. (2018). Vitamin D as potential antidepressant in outpatients with musculoskeletal pain. International Journal of Clinical Pharmacology and Therapy, 56(9), 400-410. doi: 10.5414/cp203252.

Alkhatatbeh, M. J., Abdul-Razzak, K. K., \& Khwaileh, H. N. (2021). Poor sleep quality among young adults: The role of anxiety, depression, musculoskeletal pain, and low dietary calcium intake. Perspectives in Psychiatric Care, 57(1), 117-128. doi: 10.1111/ppc.12533.

Ashworth, P. C., Davidson, K. M., \& Espie, C. A. (2010). Cognitive-behavioral factors associated with sleep quality in chronic pain patients. Behavioural Sleep Medicine, 8(1), 2839. doi: 10.1080/15402000903425587.

Gieselmann, A., Ait Aoudia, M., Carr, M., Germain, A., Gorzka, R., Holzinger, B., ... \& Pietrowsky, R. (2019). Aetiology and treatment of nightmare disorder: State of the art and future perspectives. Journal of Sleep Research, 28(4), e12820. doi: $10.1111 /$ jsr. 12820 .

Gouda, M. A. (2015). Common Pitfalls in Reporting the Use of SPSS Software. Medical principles and practice: international journal of the Kuwait University, Health Science Centre, 24(3), 300-300. doi: 10.1159/000381953.

Gureje, O., Von Korff, M., Kola, L., Demyttenaere, K., He, Y., Posada-Villa, J., ... \& Alonso, J. (2008). The relation between multiple pains and mental disorders: results from the World Mental Health Surveys. Pain, 135(1-2), 82-91. doi: 10.1016/j.pain.2007.05.005.

Hasler, B., \& Germain, A. (2009). Correlates and Treatments of Nightmares in Adults. Sleep medicine clinics, 4(4), 507-517. doi: 10.1016/j.jsmc.2009.07.012.

Holick, M. F. (2009). Vitamin D status: measurement, interpretation, and clinical application. Annals of Epidemiology, 19(2), 73-78. doi: 10.1016/j.annepidem.2007.12.001.

Krystal, A. D. (2012). Psychiatric disorders and sleep. Neurology and Clinics, 30(4), 1389-1413. doi: 10.1016/j.ncl.2012. 08.018 .

Lemyre, A., Bastien, C., \& Vallières, A. (2019). Nightmares in 
mental disorders: A review. Dreaming, 29(2), 144-166. doi: 10.1037/drm0000103.

Levin, R., \& Fireman, G. (2002). Nightmare prevalence, nightmare distress, and self-reported psychological disturbance. Sleep, 25(2), 205-212.

Levin, R., \& Nielsen, T. (2009). Nightmares, bad dreams, and emotion dysregulation: a review and new neurocognitive model of dreaming. Current Directions in Psychological Science, 18(2), 84-88. doi: 10.1111/j.1467-8721.2009. 01614.x.

Li, S. X., Zhang, B., Li, A. M., \& Wing, Y. K. (2010). Prevalence and correlates of frequent nightmares: a community-based 2-phase study. Sleep, 33(6), 774-780. doi: 10.1093/sleep/ 33.6.774.

Lima, G. A., Lima, P. D., Barros Mda, G., Vardiero, L. P., Melo, E. F., Paranhos-Neto Fde, P., ... \&Farias, M. L. (2016). Calcium intake: good for the bones but bad for the heart? An analysis of clinical studies. Archives of Endocrinology and Metabolism, 60(3), 252-263. doi: 10.1590/23593997000000173.

McCarty, D. E., Chesson, A. L., Jr., Jain, S. K., \& Marino, A. A. (2014). The link between vitamin D metabolism and sleep medicine. Sleep medicine reviews, 18(4), 311-319. doi: 10.1016/j.smrv.2013.07.001.

Nadorff, M. R., Porter, B., Rhoades, H. M., Greisinger, A. J., Kunik, M. E., \& Stanley, M. A. (2014). Bad dream frequency in older adults with generalized anxiety disorder: prevalence, correlates, and effect of cognitive behavioral treatment for anxiety. Behavioral Sleep Medicine, 12(1), 2840. doi: 10.1080/15402002.2012.755125.

Nir, Y., \& Tononi, G. (2010). Dreaming and the brain: from phenomenology to neurophysiology. Trends in cognitive sciences, 14(2), 88-100. doi: 10.1016/j.tics.2009.12.001.

Ohayon, M. M., Morselli, P. L., \& Guilleminault, C. (1997). Prevalence of nightmares and their relationship to psy- chopathology and daytime functioning in insomnia subjects. Sleep, 20(5), 340-348. doi: 10.1093/sleep/20.5.340.

Robert, G., \& Zadra, A. (2014). Thematic and content analysis of idiopathic nightmares and bad dreams. Sleep, 37(2), 409417. doi: $10.5665 /$ sleep.3426.

Romano, F., Muscogiuri, G., Di Benedetto, E., Zhukouskaya, V. V., Barrea, L., Savastano, S., ... \& Di Somma, C. (2020). Vitamin D and sleep regulation: is there a role for vitamin D? Current Pharmacology Development, 26(21), 2492-2496. doi: 10.2174/1381612826666200310145935.

Scarpelli, S., Bartolacci, C., D’Atri, A., Gorgoni, M., \& De Gennaro, L. (2019). Mental Sleep Activity and Disturbing Dreams in the Lifespan. International journal of environmental research and public health, 16(19). doi: 10.3390/ ijerph16193658.

Schredl, M. (2014). Explaining the gender difference in nightmare frequency. American Journal of Psychology, 127(2), 205-213. doi: 10.5406/amerjpsyc.127.2.0205.

Spoormaker, V. I., Schredl, M., \& van den Bout, J. (2006). Nightmares: from anxiety symptom to sleep disorder. Sleep Medical Reviews, 10(1), 19-31. doi: 10.1016/j.smrv.2005. 06.001 .

Swart, M. L., van Schagen, A. M., Lancee, J., \& van den Bout, J. (2013). Prevalence of nightmare disorder in psychiatric outpatients. Psychotheraphy and Psychosomatics, 82(4), 267-268. doi: 10.1159/000343590.

Zigmond, A. S., \& Snaith, R. P. (1983). The hospital anxiety and depression scale. Acta of Psychiatry Scandinava, 67(6), 361-370.

Zündorf, G., \& Reiser, G. (2011). Calcium dysregulation and homeostasis of neural calcium in the molecular mechanisms of neurodegenerative diseases provide multiple targets for neuroprotection. Antioxidants \& redox signaling, 14(7), 1275-1288. doi: 10.1089/ars.2010.3359. 